\title{
Pelatihan Tech for Kids untuk Meningkatkan Kesadaran dan Peminatan Siswa tentang Rekayasa sebagai Jalur Karir
}

\author{
Tech for Kids Training to Improve Student Awareness and Planning about Engineering as a \\ Career Path
}

\section{Deny Nusyirwan* \\ Lukman Hamdani \\ Hardyansah \\ Muhammad Idris Syahputra \\ Marzuki \\ Ilham Fikri \\ Tauriq Fuji Nur Akbar \\ Department of Electrical Engineering, Universitas Maritim Raja Ali Haji, Tanjung Pinang, Riau Islands, Indonesia}

*email: denynusyirwan@umrah.ac.id

Kata Kunci

Inovasi

Rekayasa

Siswa

Pelatihan

Pesisir

Keywords:

Innovation

Design

Student

Training

Coastal

Received: August 2019

Accepted: November 2019

Published: March 2020

\begin{abstract}
Abstrak
Provinsi Kepulauan Riau memerlukan kesiapan Sumber Daya Manusia yang mampu untuk bersaing di pasar global, dengan posisinya yang bersebelahan dengan negara tetangga Malaysia dan singapura dapat merupakan keuntungan dan juga sebagai kelemahan apabila SDM tidak mampu bersaing secara global. Oleh sebab itu, jurusan teknik elektro dengan program tech for kids berusaha untuk memberikan pelatihan kepribadian dan kemampuan teknis kepada anak sekolah dasar dan menengah di wilayah pesisir kota tanjung pinang. Program tech for kids menitik beratkan kepada pemahaman mengenai proses desain rekayasa untuk mampu menghasilkan inovasi dan produk yang mampu bersaing secara global dan tepat sasaran. Kegiatan yang dilaksanakan secara rutin mingguan didampingi oleh mahasiswa sebagai fasillisator yang akan membantu dosen pembimbing selama memberikan pelatihan. Pola pelatihan dan pembelajaran yang menintegrasikan kemampuan teknis desain menggunakan Autodesk inventor dengan non teknis berupa kemampuan untuk berpikir inovatif, kritis dan mampu bekerjasama sesama teman didalam kelompok akan menciptakan kepribadian yang unggul di era revolusi industry 4.0. Dari hasil pelatihan didapatkan hasil yang memuaskan dimana siswa dapat mengikuti pelatihan dengan antusias dan masih tetap bersemangat hingga ahir kegiatan. Adapun keterbatasan penggunaan perangkat komputer tidak menjadi hambatan didalam pelaksanaan di lapangan karena mahasiswa mampu mengatur jadwal pelatihan dengan baik.
\end{abstract}

\begin{abstract}
Riau Islands Province requires the readiness of Human Resources (HR) who are able to compete in the global market, with its position next to neighboring Malaysia and Singapore can be an advantage and also a weakness if $\mathrm{HR}$ is unable to compete globally. Therefore, the electrical engineering department with the tech for kids program seeks to provide personality and technical skills training to elementary and secondary school children in the coastal areas of Tanjung Pinang. The tech for kids program focuses on understanding the engineering design process to be able to produce innovations and products that are able to compete globally and on target. Activities that are carried out routinely weekly are accompanied by students as facilitators who will assist the supervisor during the training. The pattern of training and learning that integrates the technical ability of design using Autodesk inventors with nontechnical forms of the ability to think innovatively, critically and be able to work together with friends in a group will create a superior personality in the era of the industrial revolution 4.0. The training results obtained satisfactory results where students can attend the training enthusiastically and still remain enthusiastic until the end of the activity. The limited use of computer equipment is not an obstacle in the implementation in the field because students are able to manage training schedules well.
\end{abstract}




\section{PENDAHULUAN}

Saat ini peneliti mengidentifikasi bahwa pengenalan pendidikan untuk bidang rekayasa di sekolah menengah adalah periode penting untuk meningkatkan kesadaran dan peminatan siswa tentang rekayasa sebagai jalur karir. Oleh karena itu, diperlukan sebuah pendekatan yang diharapkan dapat memperkenalkan proses rekayasa pada periode tersebut, yaitu dengan mengintegrasikan proses perancangan rekayasa untuk dapat menjadi salah satu komponen pada kurikulum di sekolah menengah (Wind et. al., 2019). Selain itu juga perlu melatih pola pikir layaknya rekayasawan dengan memberikan permasalahan-permasalahan yang menantang, sehingga istilah engineering is not for me tidak akan muncul (Lucas \& Hanson, 2016). Peranan penting bagi ilmuwan pada abad ke-21 adalah berperan serta dalam mendidik masyarakat tentang metode dan hasil proses ilmiah (Kastner \& Knight, 2017). Oleh sebab itu, jurusan teknik elektro Universitas Maritim Raja Ali Haji (UMRAH) Tanjungpinang telah memperkenalkan sebuah program yang dinamakan Tech for Kids.

Tech for Kids (TFK) adalah merupakan kegiatan pengenalan proses perancangan rekayasa pada siswa dengan memperkenalkan teknologi dan rekayasa menggunakan pendekatan yang sederhana dan bersahabat, dengan tujuan untuk dapat menumbuhkan minat siswa terhadap rekayasa, dengan cara melatih para siswa untuk mampu bekerja sama, berpikir kreatif dan memahami proses untuk menghasilkan inovasi teknologi yang merupakan solusi yang tepat bagi permasalahan di lingkungannya (Pangestu et al., 2019). Selain itu, TFK juga menerapkan pola pendampingan selama pelatihan berlangsung, dengan meminta bantuan dari para mahasiswa yang disebut sebagai fasilisator untuk berinterakasi langsung dengan siswa dan siswi SD/SMP selama proses pelatihan berlangsung. Dalam program TFK ini, pemberian motivasi, membangkitkan rasa ingin tau mengenai teknologi dan pendekatan secara emosional kepada para siswa sangat diperlukan untuk menimbulkan minat para siswa mengenal proses rekayasa.

Materi-materi dasar akan diberikan pada pertemuan awal dan selanjutnya mengarahkan siswa melakukan observasi untuk dapat menemukan permasalahanpermasalahan di lingkungan sekolah. Adapun pada tahapan selanjutnya para siswa akan menentukan satu permasalahan utama, dan dengan pola curahan gagasan para siswa akan diminta kembali berdiskusi untuk memberikan solusi-solusi, pola pelatihan ini disebut divergent and convergent concept (Nusyirwan et al., 2019a). Siswa akan diminta untuk menggambarkan sebuah solusi utama terlebih dahulu diatas kertas dan selanjutnya akan didesain menggunakan perangkat lunak autodesk inventor, proses menggambar menggunakan komputer untuk dapat menghasilkan rancangan dinamakan purwarupa virtual, yang merupakan satu bagian dari proses perancangan rekayasa (Nusyirwan et al., 2019b).

Bersamaan dengan ini juga akan dilakukan pembuatan purwarupa sederhana untuk melakukan pengujian kegunaan mendapatkan pengalaman terhadap solusi yang sedang dikerjakan. Penulisan ini dimulai dengan informasi dari beberapa pola pengajaran proses desain rekayasa yang telah diterapkan pada beberapa sekolah dasar dan menengah (Pangestu et al., 2019). Selanjutnya penjelasan mengenai metodologi TFK yang dilaksanakan di sekolah dasar atau menengah di Tanjungpinang.

George Lucas Education Foundation (GEF) adalah merupakan sebuah lembaga pendidikan untuk anak tingkat sekolah dasar yang didirikan oleh George Lucas pada tahun 1991 sebagai satu bentuk usaha untuk menghasilkan siswa yang kreatif, inovatif dan koloboratif (https:/ / www.edutopia.org/). 


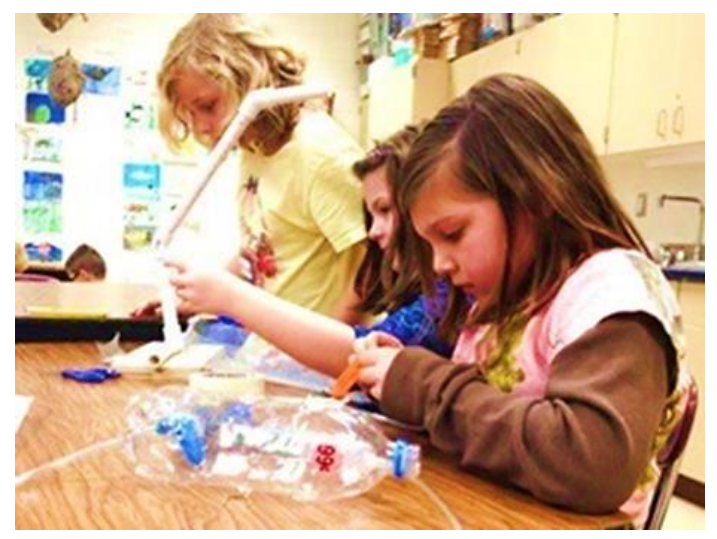

Gambar 1. Pola pembelajaran yang berbasiskan projek

Pengenalan proses perancangan rekayasa mempergunakan pendekatan pembelajaran berbasiskan projek. Kerjasama erat antara sekolah dan perguruan tinggi yang didukung oleh industri sebagai fasilisator akan mampu memberikan dukungan positif kepada anak-anak yang sedang belajar untuk mengembangkan diri masing-masing.

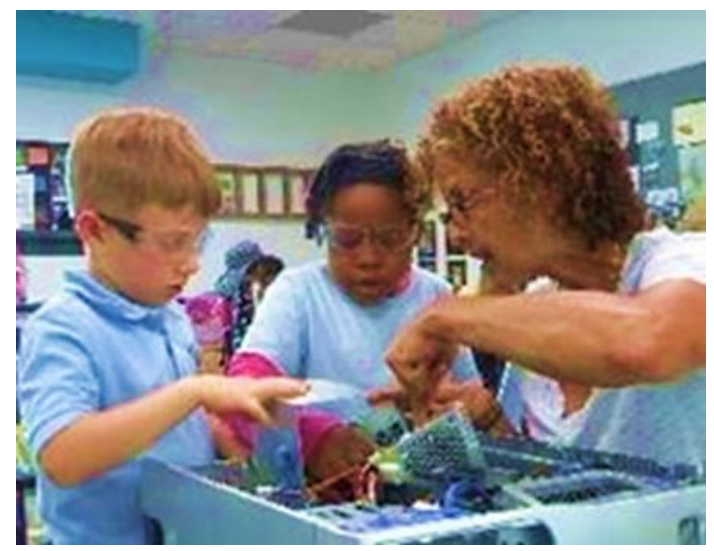

Gambar 2. Mengerjakan projek secara bersama anggota lain didalam kelompok dengan bimbingan guru sekolah

Pada Gambar 1, menampilkan pola pembelajaran yang berbasiskan projek yang sudah sangat dikenal di dunia industri, perlu juga untuk perkenalkan untuk dapat menjadi sebuah pola pembelajaran pada sekolah dasar dan menengah, dengan tujuan untuk melatih siswa dan siswi bekerja secara lebih teratur didalam melakukan tahapan-tahapan proses desain. Pada era industri 4.0, diperlukan pribadi yang mampu berkolaborasi, berkomunikasi dan memecahkan permasalahan. Siswa dan siswi diberikan kesempatan untuk mendapatkan pengalaman dengan cara mengerjakan projek secara bersama anggota lain didalam kelompok dengan tujuan untuk mendapatkan solusi bersama, seperti yang ditampilkan pada Gambar 2.

Sekolah Menengah John Adams menyediakan pendidikan yang beragam dan lengkap bagi pelajar abad ke-21 yang tertarik pada seni dan teknologi digital. Siswa dan siswi akan mengalami kurikulum yang kaya dan beragam yang mengintegrasikan seni dan teknologi digital, serta akan menjadi pemikir yang kolaboratif, kreatif, komunikatif, dan kritis; membuka jalan bagi pengalaman kehidupan nyata, peluang pasca-sekolah menengah, dan kesuksesan karier (https://www.gpisd.org).

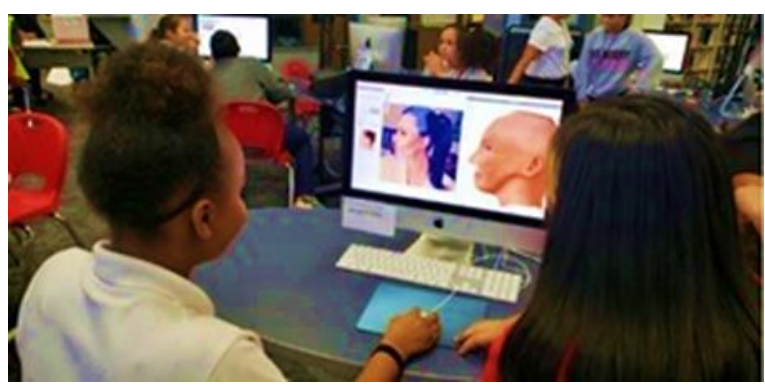

Gambar 3. Konsep pendidikan yang mengintegrasikan kurikulum dan digitalisasi

Kekuatan para siswa pada Jackson STEM Middle School berfokus pada kemampuan menerapkan Softskill yang dibutuhkan untuk tenaga kerja abad ke-21.

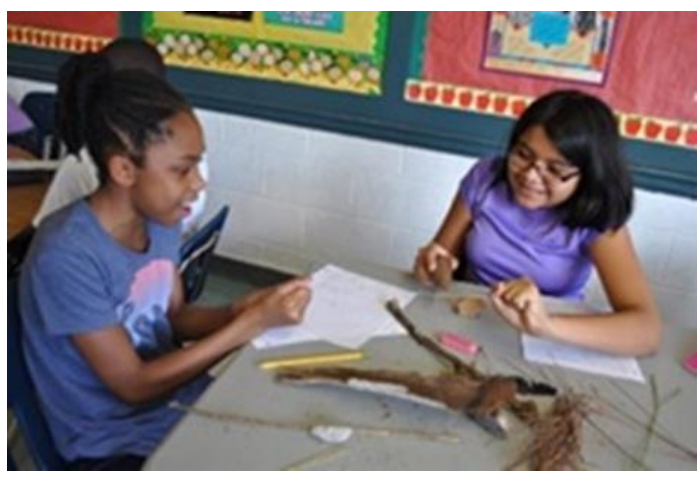

Gambar 4. Proses Desain Rekayasa sebagai identitas Jackson STEM Middle School 
Pada Gambar 4 menampilkan proses desain rekayasa sebagai identitas sekolah., selain itu keterampilan kolaboratif didalam mengerjakan projek (https://www.acpsd.net/JMS).

\section{METODOLOGI}

SDN 002 Tanjung Pinang Timur melaksanakan proses belajar pada pagi hingga siang hari dan selanjutnya pada hari tertentu dilaksanakan kegiatan extrakurikuler siswa di sore hari. Terletak di wilayah tanjung pinang. Kota Tanjung Pinang sendiri terletak di pulau Bintan, yang berdekatan dengan pulau Batam dan negara tetangga Singapura dan Malaysia.

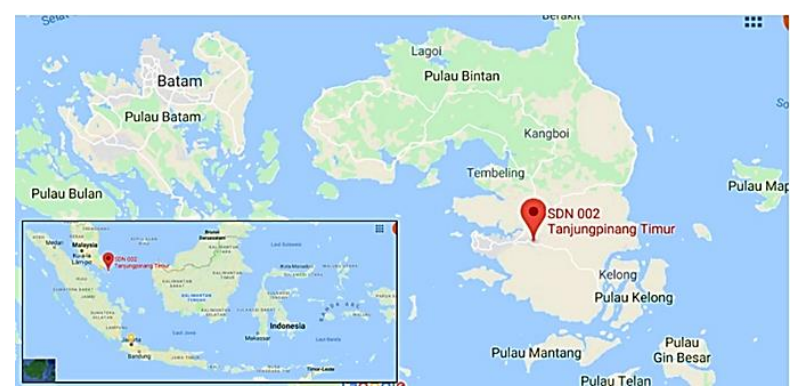

Gambar 5. Lokasi SDN 002 Tanjung Pinang Timur (https://www.google.com/maps)

Pada Gambar 5. menampilkan lokasi kegiatan TFK yang dilaksanakan di SDN 002 Tanjung Pinang Timur. Transportasi yang dipergunakan untuk menuju sekolah adalah transportasi darat. Jarak sekolah mencapai $11 \mathrm{~km}$ dari pusat kota tanjung pinang dengan menggunakan transportasi darat.

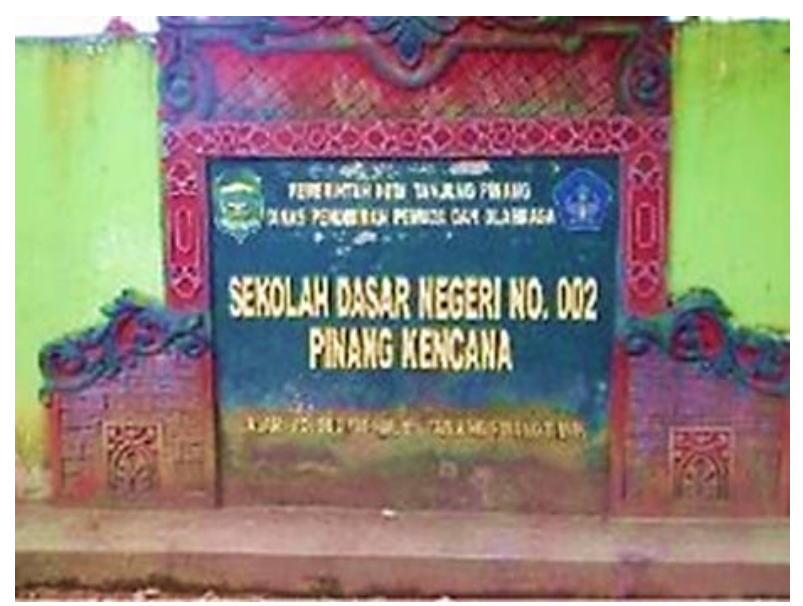

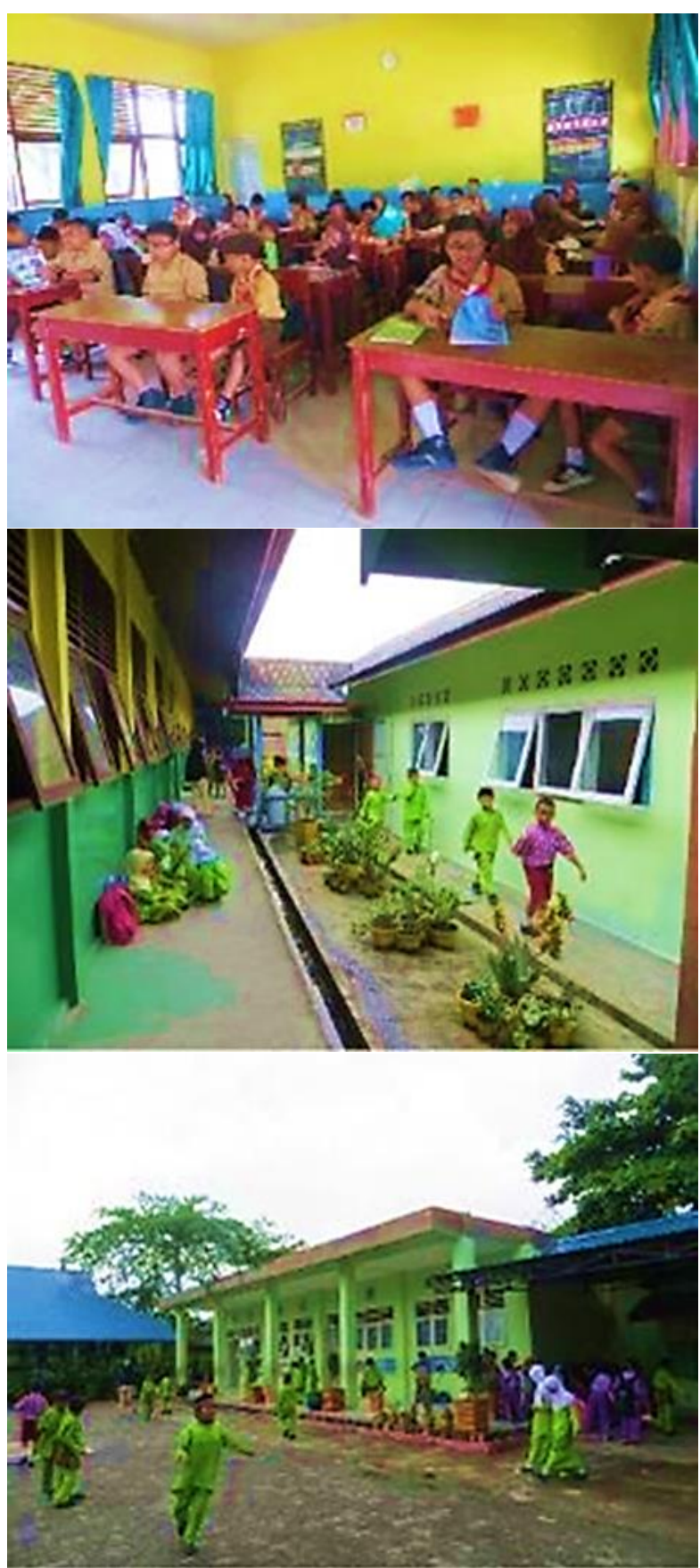

Gambar 6. Suasana di SDN 002 Tanjung Pinang Timur

Pelatihan dilaksanakan satu kali dalam seminggu yang di agendakan pada hari sabtu. Dalam pertemuan pertama diberikan pemahaman kepada siswa mengenai proses desain rekayasa beserta tahapannya. Pada minggu selanjutnya fasilisator pelatihan akan mendampingi siswa dan siswa dalam setiap tahapan hingga menghasilkan luaran pada ahir kegiatan nantinya. Pada Tabel I menampilkan Agenda Pelatihan 
Tech for Kids Tahun 2019. Adapun nama mahasiswa yang menjadi fasilisator dalam pelatihan dan siswa yang terlibat dalam pelatihan Tech for Kids ilihat Tabel II.

Tabel I. Agenda Pelatihan Tech for Kids Tahun 20192019 - Periode I

\begin{tabular}{lll}
\hline & Materi & Disampaikan Oleh \\
\hline Pertemuan & 1. Brainstroming & fasilisator pelatihan \\
1. & permasalahan & \\
& 2. Penentuan & \\
masalah utama & \\
& 3. Brainstorming & \\
solusi & \\
& 4. Sketching & \\
& (menggunakan & \\
& kertas dan & \\
pena/pensil) & \\
& 5. Menggambar & \\
& menggunakan & \\
& perangkat lunak & \\
& autodesk inventor & \\
Pertemuan & 6. Pengujian & \\
2-5 & Menggunakan & fasilisator pelatihan \\
& komputer untuk & dan siswa/i \\
& menghasilkan & \\
& purwarupa digital & \\
& menggunakan & \\
Pertemuan & Autodesk Inventor & \\
ahir & Presentasi hasil & Siswa/i \\
& pelatihan & \\
\hline
\end{tabular}

Tabel II. Data Peserta dan Fasilisator Penamping Pelatihan Tech for Kids Tahun 2019 Periode I

\begin{tabular}{|c|c|c|c|c|}
\hline $\begin{array}{c}\text { Nama } \\
\text { Sekolah }\end{array}$ & $\begin{array}{c}\text { Dosen } \\
\text { Pembimbing }\end{array}$ & & Siswa & $\begin{array}{c}\text { Fasilisator } \\
\text { pendamping }\end{array}$ \\
\hline $\begin{array}{c}\text { SDN } 002 \\
\text { Tanjung } \\
\text { Pinang } \\
\text { Timur }\end{array}$ & $\begin{array}{c}\text { Deny } \\
\text { Nusyirwan, } \\
\text { S.T., M.Sc. }\end{array}$ & $\begin{array}{l}2 . \\
3 . \\
4 . \\
5 . \\
6 . \\
7 . \\
8 . \\
9 . \\
9 .\end{array}$ & $\begin{array}{l}\text { Ivan } \\
\text { Noval } \\
\text { Rivanza } \\
\text { Willian } \\
\text { Alviyans } \\
\text { yah } \\
\text { Fadri } \\
\text { Isabil } \\
\text { Bustam } \\
\text { Aldhito } \\
\text { Edwin } \\
\text { Yusman } \\
\text { Feri } \\
\text { Hardians } \\
\text { yah } \\
\text { Candy } \\
\text { Julia Fitri } \\
\text { Syahrul } \\
\text { Aulia } \\
\text { Sazkya } \\
\text { Putri } \\
\text { Ramada } \\
\text { ni } \\
\text { Eva } \\
\text { Melisa } \\
\text { Yuda } \\
\text { Afriyan } \\
\text { syah }\end{array}$ & $\begin{array}{l}\text { 1. Lukman } \\
\text { Hamdani } \\
\text { 2. Hardyansa } \\
\text { h } \\
\text { 3. M. Idris } \\
\text { Syahputra } \\
\text { 4. Marzuki } \\
\text { 5. Ilham Fikri } \\
\text { 6. Tauriq Fuji } \\
\text { Nur Akbar }\end{array}$ \\
\hline
\end{tabular}

\begin{tabular}{ll}
\hline 11. & Farel \\
& Ganda \\
Kusuma \\
12. Ameliani \\
ta \\
Dinanti \\
13. Claresta \\
Laviola \\
Wibowo \\
14. Nabil \\
Intisar \\
Barra \\
\hline
\end{tabular}

\section{HASIL DAN PEMBAHASAN}

Kegiatan Tech for Kids dilaksanakan secara regular mingguan di sekolah dasar dan menengah di kota tanjung pinang. Beberapa sekolah telah dipilih sebagai awal kegiatan yang selanjutnya akan dikembangkan ke sekolah lainnya. Mahasiswa sebagai pelaksana lapangan akan menjadi fasilisator untuk siswa-siswi di sekolah dalam pelaksanaan kegiatan. Pada Gambar 7 menampilkan suasana ruangan pada pertemuan pertama. Fasilisator yang terdiri dari mahasiswa bersama Guru mempersiapkan keperluan untuk presentasi dan memberikan informasi awal kepada siswa mengenai kegiatan rutin mingguan mengenai proses desain rekayasa.

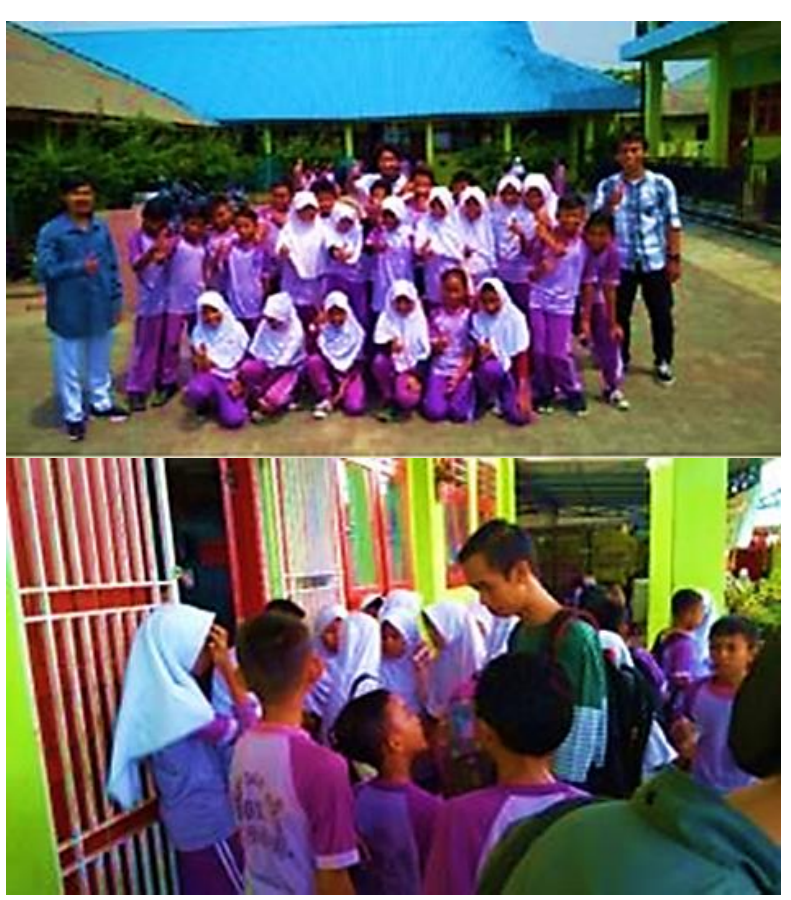




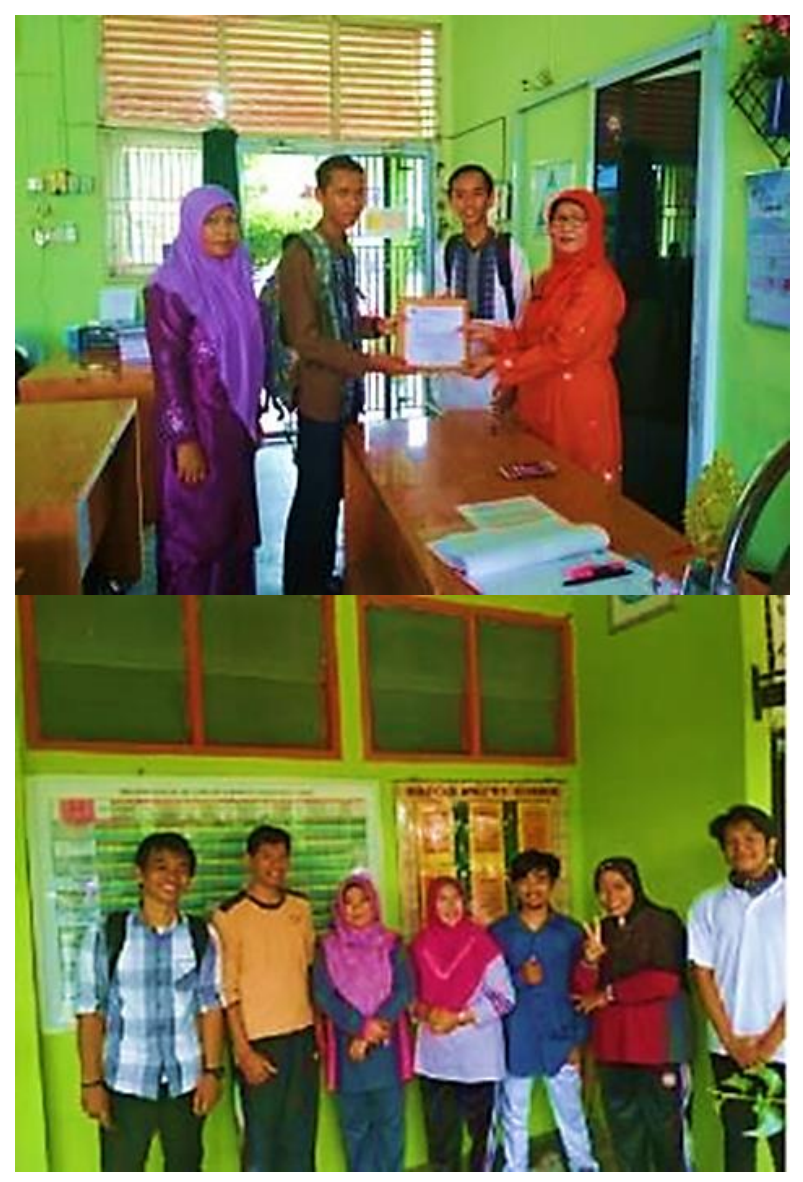

Gambar 7. Suasana sekolah pada pertemuan pertama

Setelah selesai pada tahapan awal, pengantar mengenai proses desain rekayasa kepada peserta, maka pelatihan dilanjutkan dengan tahapan berikut:

\section{Etnografi}

Saat ini teknologi yang dihasilkan adalah merupakan solusi terhadap permasalahan yang ada di masyarakat, oleh sebab itu diperlukan data yang lengkap terhadap permasalahan yang ada pada masyarakat di satu daerah. Untuk itu diperlukan pola pendekatan secara sioal yang dinamakan etnografi.

Etnografi adalah merupakan bagian awal dari Proses Desain Rekayasa, dimana dalam observasi tahapan ini diperlukan pendekatan secara sosial dan memerlukan jangka waktu tertentu didalam pelaksanaannya di lapangan. Pendekatan secara sosial berupa hidup bersama di lingkungan masyarakat dan melakukan aktifitas seperti biasa di masyarakat setempat.
Selanjutnya melakukan pendataan mengenai pola hidup masyarakat tersebut yang akan dijadikan sebagai masukan untuk inovasi berbasiskan teknologi Dengan metode observasi yang berbasiskan etnografi, peneliti akan dapat mengumpulkan data secara lengkap dengan melihat dan mengalami secara langsung peristiwa dan kondisi apa yang terjadi, hal ini sangat dianjurkan karena kesulitan yang dialami oleh pengguna untuk mengekspresikan kebutuhan dan keinginan mereka (Blindheim et al., 2019). Pada Gambar 8 menunjukkan mahasiswa sebagai fasilisator pelatihan berintegrasi langsung dengan siswa, melakukan kegiatan yang sama dan memberikan pandangan-pandangan yang diperlukan untuk melatih siswa dan siswi dalam melakukan observasi terhadap lingkungan sekitarnya.

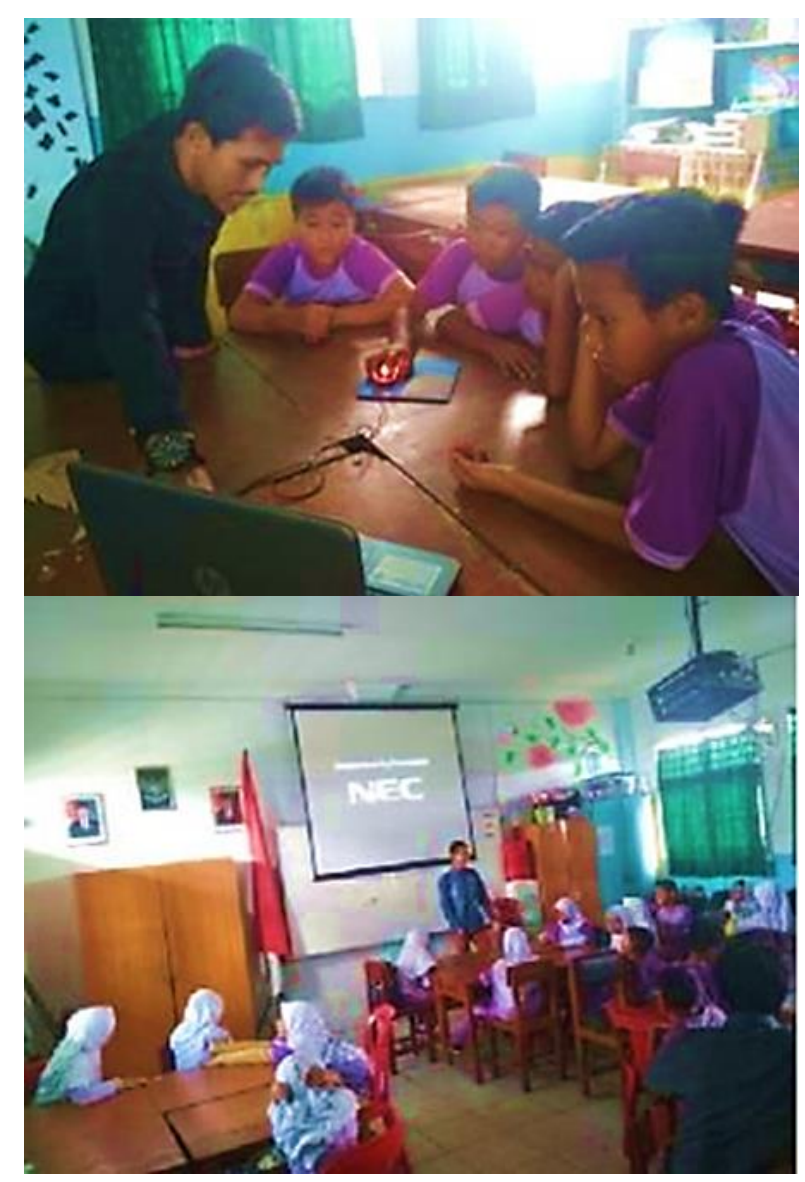




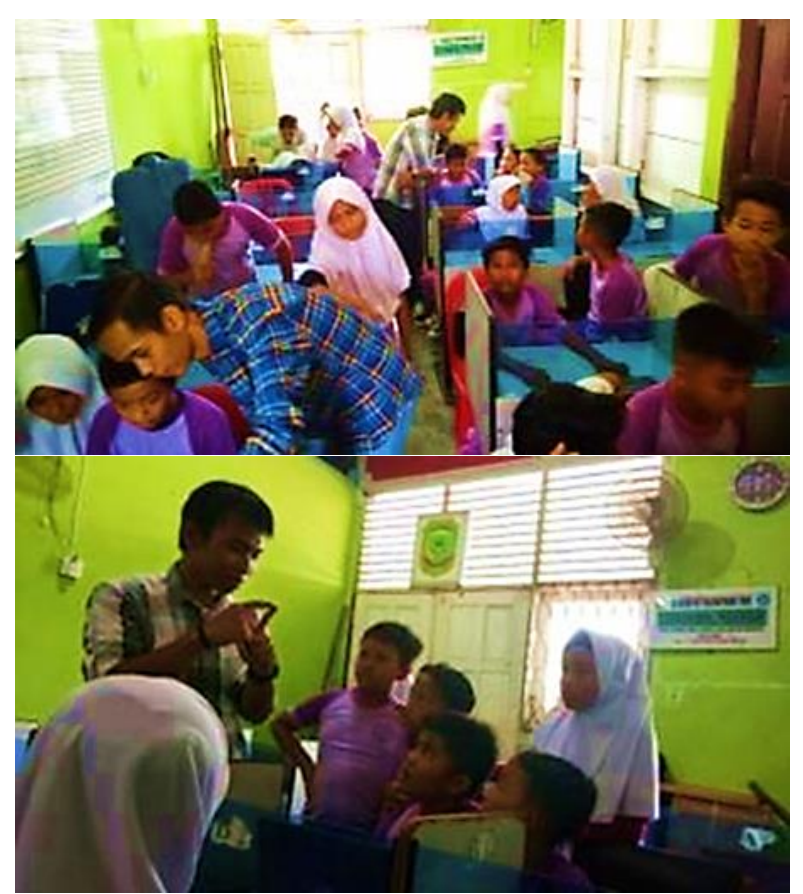

Gambar 8. Mahasiswa berintegrasi langsung dengan siswa Tech for Kids

\section{Curahan gagasan permasalahan}

Siswa dan siswi melakukan brainstorming terhadap permasalahan yang ada di sekitarnya. Masing-masing siswa menyampaikan secara cepat dengan cara menulis atau menggambar. Pada Gambar 9 menunjukkan suasana yang santai dan fun akan menghasilkan dorongan terhadap siswa dan siswi untuk mampu menemukan permasalahan-permsalahan di sekitarnya dengan lebih baik. Fasilisator akan membantu menyediakan peralatan yang diperlukan agar Brainstorming secara cepat. Pola penyampaian gagasan melalui brainstorming sangat diperlukan untuk memotivasi siswa mampu berpikir inovatif dan kratif. Curahan gagasan yang bersifat luas (divergence) adalah merupakan pondasi untuk inovasi yang berbasiskan teknologi, hal ini sering dipahami dengan $T$ concept di dalam bidang rekayasa, dimaksudkan bahwa inovasi yang dihasilkan memiliki pengaruh yang luas dan mendalam.

Adapun aturan-aturan di dalam brainstorming adalah menghindari penilaian secara langsung dan membantah ide yang sedang disampaikan., mendorong adanya ideide yang luar biasa/aneh, berpikir seperti anak kecil dimana tidak takut akan kesalahan., mengedepankan kuantitas daripada kualitas., mempertahankan semua pembicaraan dan diskusi serta ide yang disampaikan tetap pada topik dan tidak ada yang berbicara secara bersamaan (Nusyirwan, 2018).

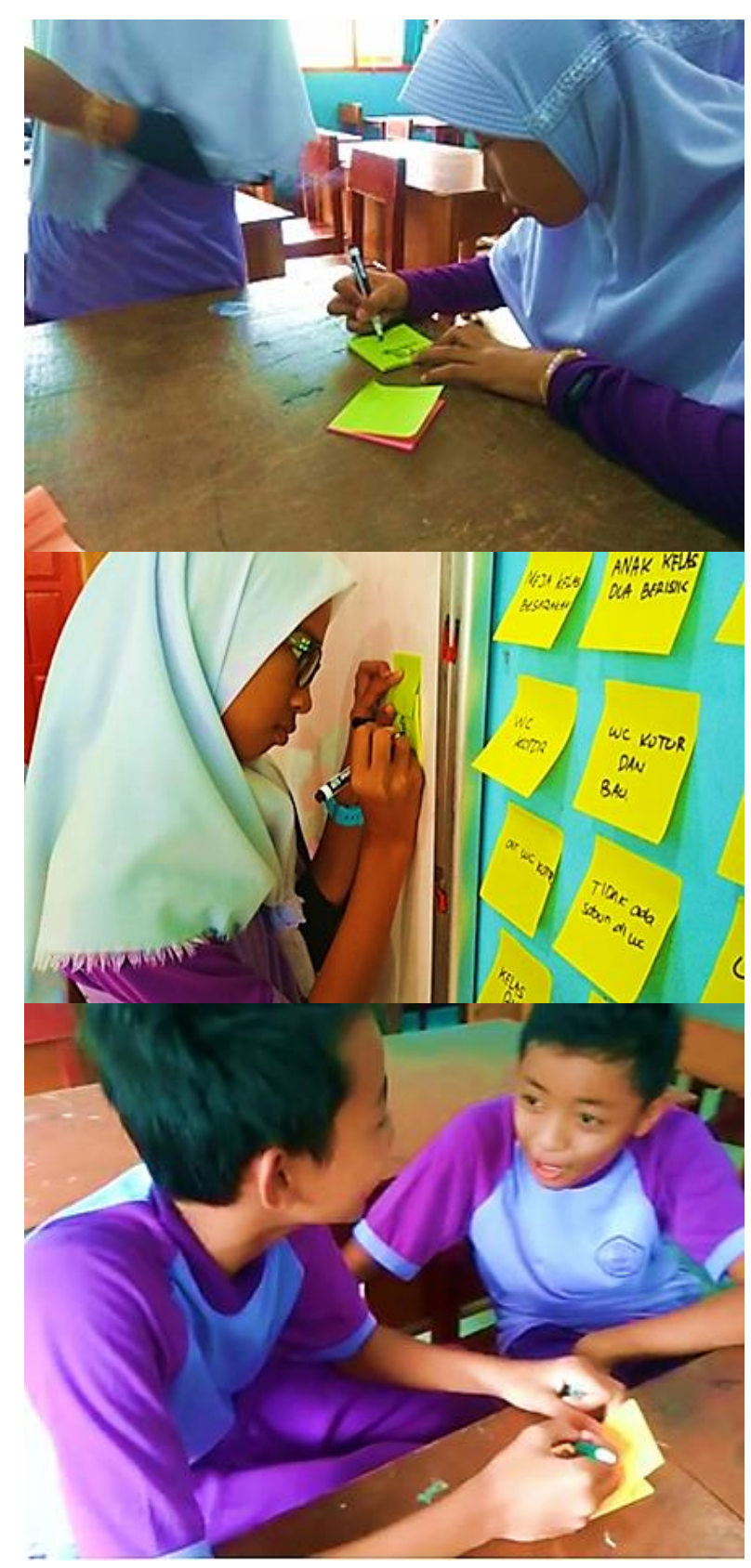




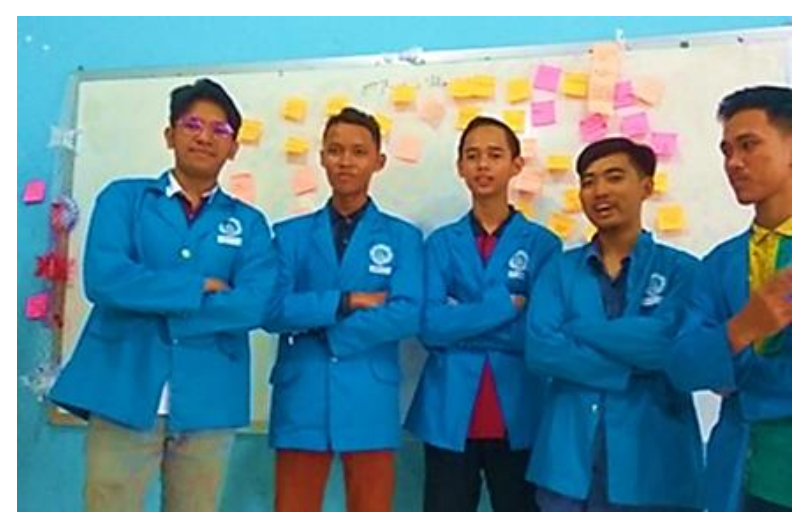

Gambar 9. Siswa dan siswi melakukan curahan gagasan

\section{Menentukan permasalahan utama}

Setelah mengumpulkan permasalahan-permasalahan yang ada di sekolah, selanjutnya akan dilakukan pengelompokan untuk menentukan permasalahan utama nantinya. Permasalahan utama adalah permasalahan yang akan di angkat untuk langkah penentuan solusi, dalam tahapan ini akan di pilih satu masalah saja. Proses diskusi bersama sesama anggota kelompok, selanjutnya memberikan penjelasan terhadap masalah yang akan dijadikan masalah utama. Dalam proses ini perlu dipertimbangkan adalah keputusan yang akan diambil adalah merupakan keputusan bersama anggota lainnya. Gambar 10 menunjukkan proses pengelompokan yang dilakukan didepan kelas secara langsung sehingga dapat dilakukan diskusi internal kelompok, dimana setiap anggota diminta untuk aktif menyampaikan pendapat. Pada tahapan ini dilakukan proses convergence terhadap permasalahan.

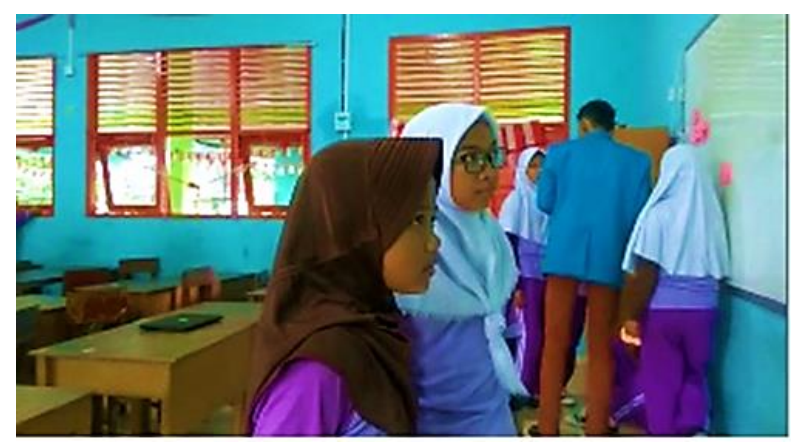

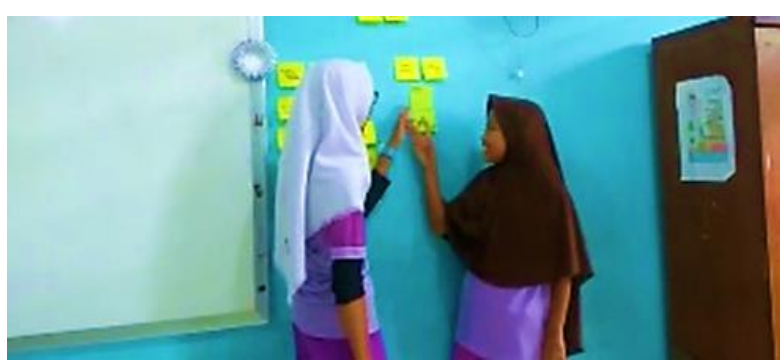

Gambar 10. Pengelompokan yang dilakukan secara langsung sesama anggota keompok untuk menentukan permasalahan utama

\section{Penentuan solusi}

Tahapan selanjutnya adalah proses divergence terhadap permasalahan utama. Beberapa konsep solusi akan diutarakan melalui proses brainstorming bersama anggota lainnya dengan mempergunakan kertas untuk menulis atau menggambatkan solusi. Pada ahir tahapan ini adalah pemilihan satu konsep solusi yang akan dikerjakan pada tahapan selanjutnya. Solusi utama yang diambil adalah merupakan solusi yang akan berdampak luas untuk masyarakat nantinya. Pada Gambar 11 menunjukkan proses curahan gagasan kembali dilakukan untuk memberikan kesempatan kepada siswa-siswi untuk berpikir secara bebas menyampaikan pendapat dengan menggunakan kertas. Setelah tahapan divergence solution selesai, maka siswa dan siswi akan menentukan satu solusi yang akan dijadikan sebagai landasan ke tahapan selanjutnya.

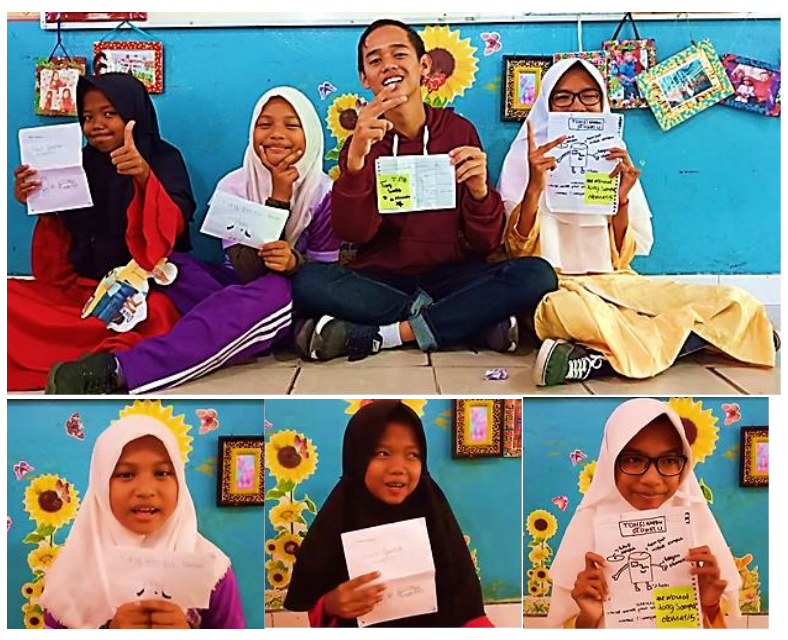

Gambar 11. Proses curahan gagasan untuk mendorong siswa meberikan solusi secara bebas 


\section{Sketching}

Sketching diperlukan oleh siswa untuk mampu mendorong ide-ide yang bisa disampaikan lewat brainstorming. Sedangkan untuk pengguna teknologi, akan dapat melihat konsep awal dari solusi yang diberikan. Diskusi secara internal kelompok dapat dilakukan untuk memberikan masukan terhadap rancangan awal. Sangat didorong untuk menggunakan kertas dan pensil karena akan lebih mudah melakukan perubahan jika ada ide lainnya yang akan dikembangkan.

Teknik mensketsa secara manual sesuai untuk menyampaikan ide pada tahapan awal dari penelitian, dimana teknik ini sudah diterapkan oleh perancang (designer) di dunia industri. Metode perancangan yang menggunakan kertas dan pensil ataupun bahan-bahan pendukung lain sangat dianjurkan untuk menurunkan biaya didalam penelitian. Selain itu tujuan sketsa dalam domain teknik adalah menyediakan komunikasi dan pengambilan keputusan yang lebih cepat pada tahap awal desain, dengan memberikan gabungan visual dan faktual deskripsi untuk peningkatan evaluasi dan pemilihan konsep (Yim \& Lee, 2015). Sketsa desain tidak menggambar sesuatu yang sudah ada, sebagai contoh gambar tokoh, gambar benda hidup dan sejenisnya. Sebaliknya sang desainer terlibat dalam proses berusaha memberikan definisi eksternal kepada sesuatu yang dibayangkan (Tovey et al., 2003). Pada Gambar 12 dapat dilihat hasil rancangan yang dilakukan oleh siswa.

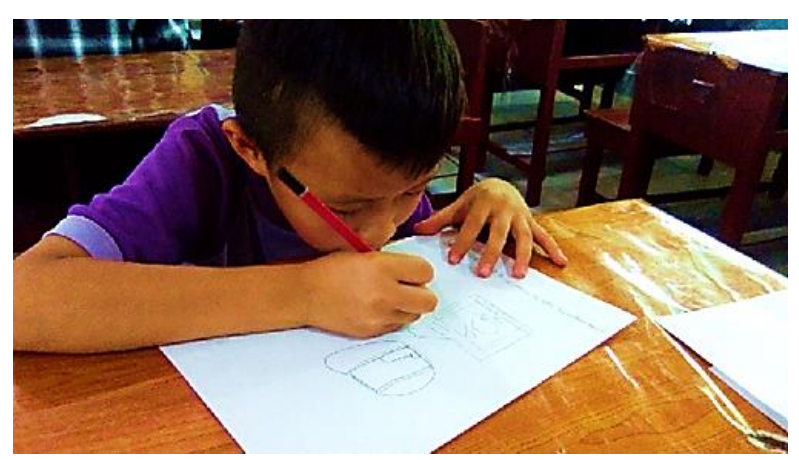

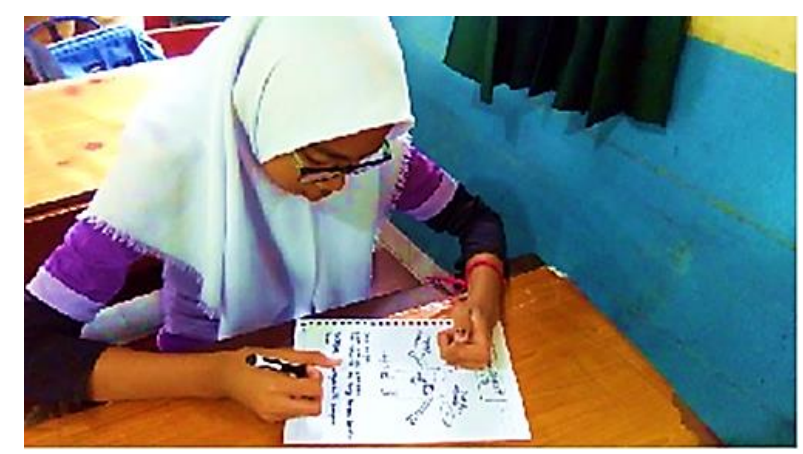

Gambar 12. Mensketsa di atas kertas

\section{Purwarupa Virtual}

Dalam tahapan ini, telah dimulai menggambar menggunakan komputer untuk mendapatkan tampilan detil awal secara virtual 3 dimensi. Beberapa perubahan dapat dikerjakan secara langsung. Pada Gambar 13 menunjukkan siswa melakukan proses transformasi dari sketsa yang digambar di atas kertas ke komputer. Desainer menggunakan model virtual untuk menggantikan purwarupa nyata dan menganalisisnya menggunakan berbagai jenis simulasi yang bertujuan untuk menciptakan kembali kondisi kehidupan nyata di mana produk perlu beroperasi. Proses ini dibantu oleh program komputer modern, yang dibuat untuk membantu para rekayasawan modern dalam pekerjaan mereka. Model virtual dibuat akan mencerminkan gambar nyata, atau sedekat mungkin dengan nyata (Łukaszewicz, 2017). Keuntungan utama dari purwarupa virtual adalah pembuatan purwarupa dari konsep inovasi untuk pengujian awal tidak diperlukan karena setiap penyesuaian akan dilakukan secara langsung dalam realitas virtual dengan mempergunakan simulasi. Purwarupa dapat di explorasi secara virtual dan interaktif, selanjutnya dapat dipelajari dan disimulasikan sebelum implementasi di dunia nyata (Wang, 2011). 


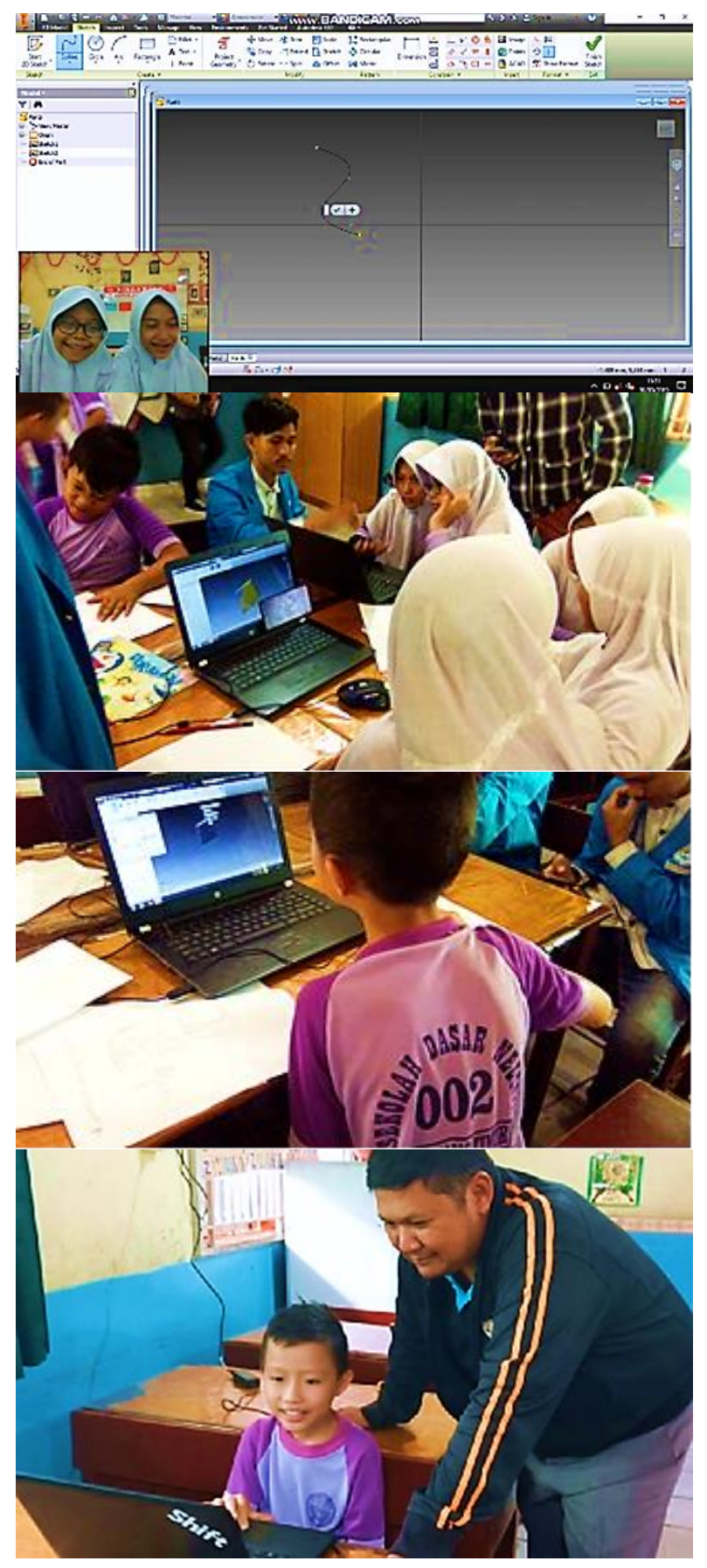

Gambar 13. Pembuatan purwarupa virtual dari hasil sketsa

Setelah selesai Tech for Kids, mahasiswa sebagai fasilisator memberikan sertifikat pelatihan kepada siswa yang disaksikan oleh Dosen Pembimbing, sebagaimana disajikan pada Gambar 14.

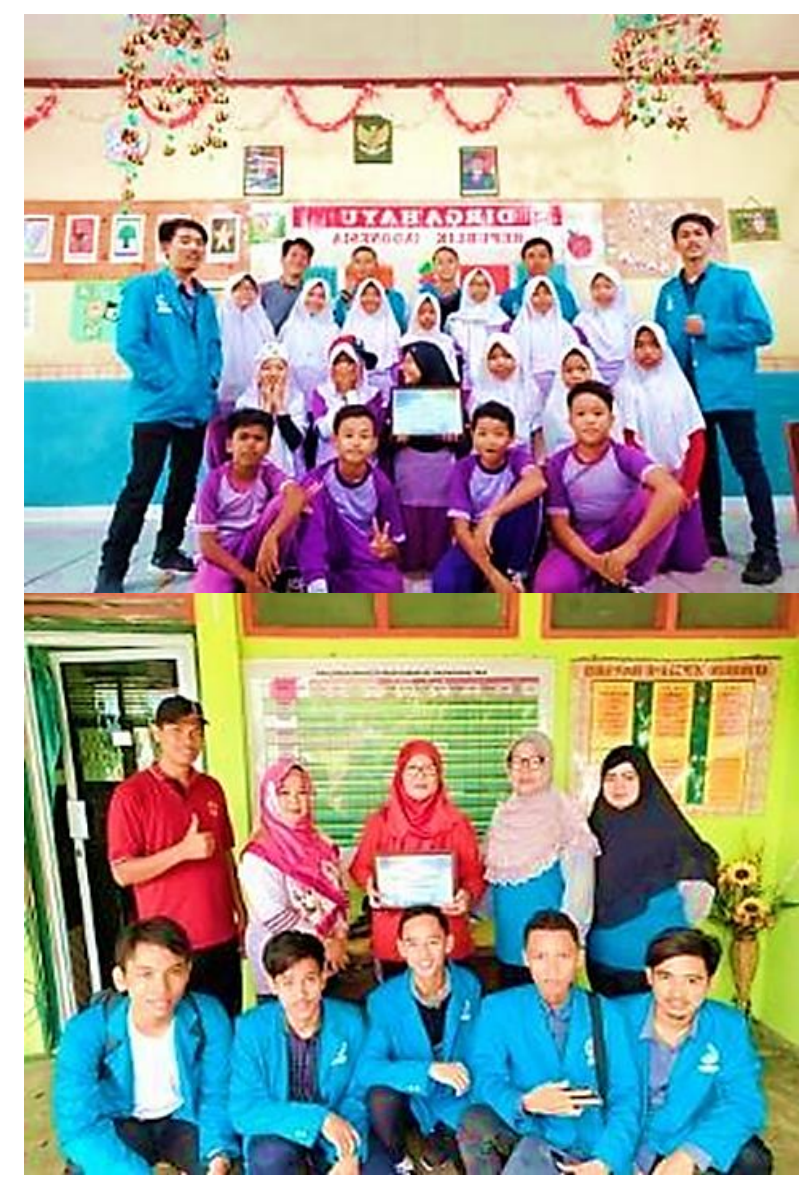

Gambar 14. Fasilisator memberikan sertifikat pelatihan kepada siswa dan sertifkat terima kasih kepada sekolah

\section{KESIMPULAN}

Tech for Kids adalah pengenalan proses perancangan rekayasa pada siswa sekolah dasar dan menengah. Pelatihan ini dimaksudkan untuk memberikan kemampuan teknis siswa menggunakan perangkat lunak Autodesk inventor untuk menggambarkan purwarupa virtual tiga dimensi. Selain hal tersebut, dengan pelatihan yang diberikan siswa juga diharapkan akan mampu bekerja sama, berpikir kreatif dan memahami proses perancangan rekayasa untuk menghasilkan inovasi teknologi yang merupakan solusi yang tepat bagi permasalahan di lingkungannya. Siswa yang mengikuti pelatihan diberikan kesempatan untuk mendapatkan pengalaman dengan bekerja bersama anggota lain didalam kelompok dengan tujuan untuk 
mendapatkan solusi bersama. Sekolah berharap, Tech for Kids dapat menjadi kegiatan terjadwal untuk kedepannya. Tech for Kids adalah satu bentuk kegiatan pelatihan yang dapat dilaksanakan akibat adanya kerjasama yang baik dengan pihak sekolah, diharapkan untuk kedepannya dapat juga melibatkan pemerintah daerah untuk mengadakan kegiatan serupa untuk memasyarakatkan teknologi pada anak usia sekolah, dengan demikian akan mempersiapkan generasi yang mampu bersaing secara global. Dengan adanya mahasiswa sebagai fasilisator, dapat mendorong siswa untuk lebih antusias didalam memahami materi proses perancangan rekayasa, oleh sebab itu pola seperti ini juga dapat diterapkan di sekolah untuk mata pelajaran tertentu yang mengajarkan ilmu teknik

\section{UCAPAN TERIMA KASIH}

Terima kasih kepada ketua jurusan dan rekan di jurusan teknik elektro UMRAH serta Sekolah Dasar Negeri 002 Tanjung Pinang Timur yang telah memberikan kesempatan melakukan Tech for Kids dalam rangka mempersiapkan inovator dan technopreneuer di masa depan.

\section{REFERENSI}

Blindheim, J., Wulvik, A., Steinert, M. 2016. Using Secondary Video Material For User Observation In The Needfinding Process For New Product Development And Design. In Proceedings of the DESIGN 2016 14th International Design Conference. 1845-1854. Sociotechnical Issues in Design.

Kastner, S., Knight, R.T. 2017. Bringing Kids into the Scientific Review Process. Neuron. 93(1):12-14. https://doi.org/10.1016/j.neuron.2016.12.002

Lucas, B., Hanson, J. 2016. Thinking Like an Engineer: Using Engineering Habits of Mind and Signature Pedagogies to Redesign Engineering Education. International Journal of Engineering Pedadogy. 6(2):4-13.
Eukaszewicz, K. 2017. Use of CAD Software in the Process of Virtual Prototyping of Machinery. Procedia Engineering. 182:425-433. https://doi.org/10.1016/j.proeng.2017.03.127

Nusyirwan, D., Prayetno, E., Singer, H.A., Nugraha, S., Yunianto, A.H., Suhendra, T., Hadi, A., Shafira, A., Oktavia, D., Sinaga, L.A. 2019a. Pelatihan Edutech For Children Untuk Meningkatkan Kemampuan Teknis Dan Melatih Pola Pikir Inovatif Siswa. Logista: Jurnal Ilmiah Pengabdian kepada Masyarakat. 3(2):187-198.

https://doi.org/10.25077/logista.3.2.187198.2019

Nusyirwan, D., Suhendra, T., Fadillah, M.A., Saputra, O.I. 2019b. Tech for Kids Sebagai Pelatihan Pengenalan Proses Perancangan Rekayasa Di Smpn 11 Tanjung Pinang. Jurnal Pemberdayaan: Publikasi Hasil Pengabdian Kepada Masyarakat. 3(2):159-172. https://doi.org/10.12928/jp.v3i2.885

Nusyirwan, D. 2018. Design Thinking Sebagai Bridge of Innovation Perguruan Tinggi dan Industri di Jurusan Teknik Elektro Universitas Maritim Raja Ali Haji (UMRAH). Jurnal Sustainable: Jurnal Hasil Penelitian dan Industri Terapan. 7(2):86-94.

https://doi.org/10.31629/sustainable.v7i2.45 1

Pangestu, M.Y., Wijaya, S.B., Ajay, A., Oktavia, D., Amrullah, M.Z., Ahmadi, A., Nugraha, H.A. 2019. Peran Perguruan Tinggi Melalui Tech for Kids Dalam Usaha Mendorong Siswa Minat Terhadap Ilmu-Ilmu Teknik. In Prosiding Seminar Nasional Pengabdian Masyarakat LPPM UMJ Semnaskat 2019. Jakarta: Universitas Muhammadiyah Jakarta.

Tovey, M., Porter, S., Newman, R. 2003. Sketching, concept development and automotive design. Design Studies. 24(2):135-153. https://doi.org/10.1016/S0142694X(02)00035-2

Wang, Z. 2011. Interactive virtual prototyping of a mechanical system considering the environment effect. Part 2: Simulation quality. Comptes Rendus Mécanique. 339(9):605-615. https://doi.org/10.1016/j.crme.2011.06.003

Wind, S.A., Alemdar, M., Lingle, J.A., Moore, R., Asilkalkan, A. 2019. Exploring student 
understanding of the engineering design process using distractor analysis. International Journal of STEM Education. 6:4. https://doi.org/10.1186/s40594-018-0156-x

Yim, H., Lee, K. 2015. Preliminary Modular Design for Electric Personal Mobility with DesignEngineering Collaboration. World Electric Vehicle Association. 7(3):426-435. https://doi.org/10.3390/wevj7030426 